\title{
ARCHAEOLOGICAL PRACTICE IN QUÉBEC CITY, A UNESCO WORLD HERITAGE CITY
}

\author{
Prática arqueológica na cidade de Quebec, uma \\ cidade Patrimônio Mundial da UNESCO
}

William Moss*

\begin{abstract}
Archaeology is recognized as a tool for economic development and for social engagement. The municipal level is increasingly seen as the locus for protecting archaeological heritage resources and for engaging the public. Being responsible for a UNESCO World Heritage site, the municipal government of the City of Québec has developed an approach that stands at the juncture of governance and public participation, of legislation and practice. The municipal government has one of the longest-standing archeology programmes in Canada and has been a witness to changes in governance and practice over the past half century. City archaeologists are currently preparing an archaeological master plan in the context of renewed heritage legislation in the province of Québec. This will be accompanied by policies and programmes designed to foster public interest and promote public participation in the process.
\end{abstract}

Keywords: Legislation; archaeological resource management; development; Québec; commemoration

\section{RÉSUMÉ}

L'archéologie est reconnue comme instrument d'engagement social et de développement économique. Le palier municipal est de plus en plus reconnu comme lieu de prédilection pour la protection du patrimoine culturel archéologique et plus l'implication citoyenne. En tant que site du patrimoine mondial

* Chief Archaeologist. Ville de Québec , 295, boulevard Charest Est - Québec QC Canada G1K 3K8. E-mail: william.mosss@ ville.quebec.qc.ca 
de l’UNESCO, la Ville de Québec a élaboré une approche qui fait le pont entre la gouvernance et la participation publique, entre la législation et la pratique. Le programme archéologique élaboré par la Ville se compte parmi les plus anciens au Canada et peut témoigner des changements à la gouvernance et à la pratique depuis un demi-siècle. Les archéologues municipaux préparent présentement un plan directeur dans le contexte d'une législation sur le patrimoine récemment renouvelée par la province de Québec. Ce plan sera accompagné par une politique et de programmes facilitant la participation des citoyens au processus de gestion et de mise en valeur de ce patrimoine.

Mots-clés: Législation; gestion des ressources archéologiques; développement; Québec; commémoration

\section{RESUMO}

A arqueologia é conhecida como ferramenta de desenvolvimento econômico assim como meio de engajamento social. O nível municipal está sendo, cada vez mais, visto como o meio privilegiado para a proteção do patrimônio cultural arqueológico e a participação cidadã. Enquanto sitio do patrimônio mundial da UNESCO, a cidade de Quebec desenvolveu uma abordagem conectando governança e participação publica, assim como legislação e prática. O programa arqueológico da cidade de Quebec conta entre os mais antigos no Canadá e ilustra as evoluções na governança e na prática arqueológicas desde os últimos cinquenta anos. Os arqueólogos da cidade de Quebec trabalham atualmente em preparar um plano diretor arqueológico no contexto da atualização da legislação do patrimônio na província canadense de Quebec. Este plano será acompanhado por politicas e programas pensados para favorecer o interesse público bem como promover a participação da população nesse processo de gestão e valorização desse patrimônio.

Palavras-chave: Legislação; gestão dos recursos arqueológicos; desenvolvimento; Québec; comemoração

\section{Introduction}

Québec City has a population of 536,000 people in an urban region of 790,000 inhabitants; it covers a territory of 463 square kilometers, or 178 square miles (CMQ, 2015). This territory includes four historic districts defined by the province's Cultural Heritage Act 
(ÉDITEUR OFFICIEL DU QUÉBEC, 2017), which, together, represent one third of designated historic districts in the province (Figure 1). One of the four, The Historic District of Old Québec, is listed as a UNESCO World Heritage site, ${ }^{1}$ one of two such sites in Canada. The city is comprised of more than twenty former village centres, several going back to the first decades of the $17^{\text {th }}$ century French colony in the New World. These centres were subsumed by the modern city in a series of annexations beginning in 1889 , with the most recent taking place in 2002. The city sits at the junction of three major geological regions of the northeastern portion of the continent and has experienced significant environmental change throughout the Holocene. For these reasons, Québec City has a particularly rich and varied heritage, seen in its similarly rich and varied archaeological sites (MOSS, 1993; MOUSSETTE \& WASELKOV, 2013, p. 217257).

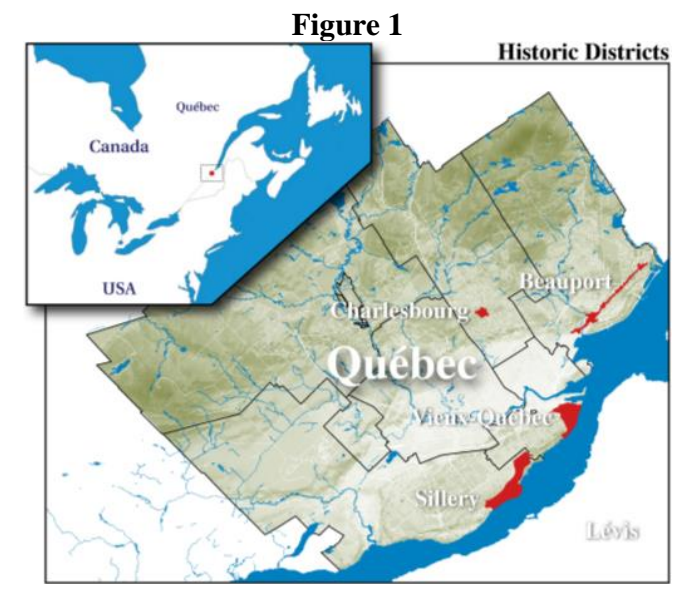

Map of Québec City and the four historic districts defined by the provincial Cultural Heritage Act. (Graphics by André Tanguay; courtesy of Ville de Québec.)

Numerous institutions are involved in research, site preservation, and site interpretation. These include the federal government's Parks Canada Agency, the provincial government's 
Ministère de la Culture et des Communications (MCC) and its Commission de la Capitale nationale du Québec (CCNQ), Université Laval, and the municipal administration of Ville de Québec (hereafter the City of Québec). The City occupies a central position in this matrix, one reason being its direct relations with all citizens, including members of the corporate world, property developers, and residents. Furthermore, municipal administrations are the closest level of government to the population, and numerous individuals and associations are active participants in municipal processes. The City adopted heritage policy recognizing the contribution of archaeological heritage to the general economy (VILLE DE QUÉBEC, 2007, p. 47), and it is currently developing a long-term vision of heritage in order to plan for the coming decades (VILLE DE QUÉBEC, 2016). The City has played an active role over the past quarter century and has had considerable success in heritage preservation, particularly through partnerships with different stakeholders. This article will examine several of these partnerships and situate them in the context of recently adopted heritage legislation that will change the various roles and responsibilities of different levels of government for decades to come. It will examine the contribution that these partnerships have made to the local and the national community, and it will conclude with a critique of current practice, stemming from questions recently posed by Shannon Dawdy in a plenary address to the Society for American Archaeology: "Should archaeology be useful?" or "Can archaeology save the world?" (DAWDY, 2009a). This address, given in a session looking at the state of archaeology in the new millennium, critiques current practice as a self-serving appendage of "heritage, more concerned with tradition and imagined pasts than with future possibilities."

\section{An Overview of Québec City and Its Archaeology}

Archaeology in Québec City is an extension of the province of Québec's distinctive approach to archaeological practice. The 
City's approach therefore differs from many other models within North America (BAUGHER et al., 2017), as emphasis has focussed on developing knowledge of the city's archaeological heritage, creating attractive urban spaces through innovative place making, and actively fostering public education.

\subsection{General Approach}

Québec City - the geographic entity, as opposed to the political administration, the City of Québec - is characterized by a community of researchers working for a series of institutions. This synergy has generated important results, the most recent example being a compendium of research in the context of the $400^{\text {th }}$ anniversary of the founding of the city in 1608 (MOSS, 2009a; MOSS, 2009b). This publication presents an interesting collection of research papers resulting from important signature projects, such as the provincial government's Place-Royale programme of the 1970s and 1980s; Parks Canada's Fortifications of Québec programme from the 1980s until the 2000s; Universite Laval's Îlot des Palais programme beginning in 1982; and the provincial Commission de la Capitale nationale's programme on the $16^{\text {th }}$ century Cartier-Roberval site (SAMSON \& FISET, 2013), among others.

The City administration itself has had an active archaeological programme since the eve of the listing of The Historic District of Old Québec on the UNESCO World Heritage registry in 1985, at which time it created a position for a City Archaeologist, the first of its kind in Canada (Figure 2). The City promotes a collaborative approach in partnership with a number of institutional and corporate partners. The approach is characterized by the concept of "vivre ensemble," or "living together," which is fundamentally important in an urban context where archaeologists, town planners, promoters, and whole populations must live, work, and advance into the future together. ${ }^{2}$ One of the most successful examples of this is

2 Dufay et al. $(2014$, p. 3$)$ describe "vivre ensemble" as: "Ce territoire si particulier, où se succèdent et cohabitent des populations diverses, est par définition le siège du 'vivre ensemble'." 
seen in the City's long-standing collaboration with the provincial government and with Université Laval.

Figure 2

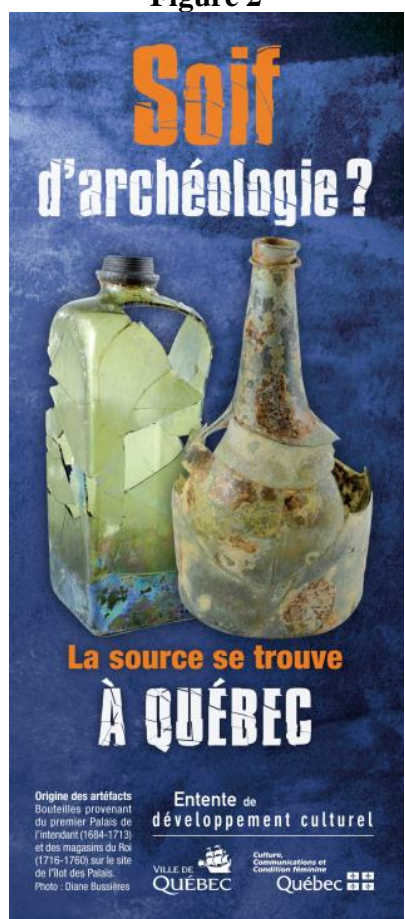

The City has put considerable effort into interpreting its archaeological heritage for the general public. This advertisement, used in local newspapers and regional heritage magazines, highlights the work of Québec City in the province of Québec. (Courtesy of Ville de Québec.)

Under the Cultural Properties Act, which preceded the 2012 Cultural Heritage $\mathrm{Act}^{3}$, the bulk of the City's actions were carried out

$$
3 \text { Cultural Heritage Act } 2012 \text { (in English) }
$$
http://legisquebec.gouv.qc.ca/en/ShowDoc/cs/P-9.002, Loi sur le patrimoine culturel (en français) http://legisquebec.gouv.qc.ca/fr/ShowDoc/cs/P-9.002 
within the terms of a series of memoranda of agreement concluded with the provincial MCC beginning in 1979. Known as Entente sur le développement culturel, these long-term memoranda of agreement (for five- or, more recently, three-year periods) covered a wide range of cultural and heritage projects, including archaeological research and site interpretation. The orientations and programmes were identified by each agreement, and projects were developed through yearly, jointly approved programming. Costs were shared on a 50/50 basis between the provincial MCC and the City of Québec. Although archaeology was only a very small portion of each memorandum of agreement's objectives and concomitant budgets, the availability of funds that were guaranteed on an annual basis greatly enhanced the City's capacity for action. It also allowed for the development of new projects and perspectives that went beyond the simple rescue of sites and data that often occurs in urban development projects.

Development projects for historic districts were submitted to the City Archaeologist by the City's planning department and the respective boroughs. The nature and scope of research, site protection, and site interpretation were negotiated with project promoters by the City Archaeologist. Research was carried out by the City's archaeological team or with private contractors mandated and funded by the City within the annual budget of each Entente sur le développement culturel.

The City and Université Laval are particularly close partners, and they have worked together annually since 1982 . Since 1985 , they have concluded a series of memoranda of agreement mirroring the Entente sur le développement culturel documents between the City of Québec and the province. These memoranda offer financial and technical support to the university's field school, which has been held on municipal properties since 1982, except for a brief period when it was held on the Hunt Block site from 1993-1996 (ROY, 2012). This collaboration has notably produced a series of publications by Laval students and City-mandated archaeologists in the series Cahiers d'archéologie du CELAT, as well as in earlier series. ${ }^{4}$ In an early

4 CÉLAT stands for Centre de recherches cultures - arts - sociétés, formerly Centre interuniversitaire d'études sur les lettres, les arts et les traditions. The CÉLAT website provides a 
agreement between the two organisations, Université Laval developed an ecosystem model for use by the City to orient research on major and minor sites in the context of urban infrastructure programmes (L'ANGLAIS, 1994). While this model is due for updating, it has fostered internal coherence amongst initially disparate small-scale projects in different parts of the city (MOUSSETTE \& MOSS, 2010). The City Archaeologist and the university faculty responsible for the field school are members of the CÉLAT research centre, and their collaboration is fully congruent with the central "vivre ensemble" concept of the CÉLAT's research activities.

Other examples of successful research projects carried out on private properties with the collaboration of site owners include the Séminaire de Québec (MOSS, 2005; SIMONEAU, 2008a), the Anglican Cathedral (ROULEAU et al., 1998a), and the Auberge Saint-Antoine, also known as the Hunt Block site (SIMONEAU, 2008b). General overviews of these and other projects can be consulted in several publications (see AUGER \& MOSS, 2001; MOSS, 2009a; ROULEAU, 2014). Other recent collaborations have taken place with the local indigenous nation, the Huron-Wendat First Nation.

\subsection{Public Benefits}

Tourism is a major part of the regional economy. In 2012, more than 4.7 million tourists visited the city, and 1.2 million (25\%) of them visited a historic site, generating over $\$ 514$ million in revenue (STATISTICS CANADA, 2016). Tourism and culture account for $3.1 \%$ of the jobs in the region, thereby ranking fourth in importance for this indicator (GENOIS LEDUC \& LEDUC, 2016).

Archaeology contributes to the attractiveness of the city. Although specific statistics on archaeology are not available, one anecdote suggests its importance: during the 2008 field excavations, which were open to the public, Parks Canada's Saint-Louis Forts and Châteaux National Historic Site, strategically situated under the

full list of these publications: www.celat.ulaval.ca/recherches-2/publications/cahiers-darcheologiedu-celat/ 
Dufferin Terrace, in the shadow of the Fairmont le Château Frontenac hotel, had the highest number of visitors for the national agency's historic sites network in the whole country (MICHAUD, 2009, personal communication). A recent publication presenting an overview of archaeological sites that can be visited throughout the province of Québec describes seventeen sites that are open to visitors in Québec City, including Parks Canada's Fortifications of Québec National Historic Site, the provincial government's Musée de la Place Royale, and the City's Îlot des Palais site, which was the location of Université Laval's field school (ARCHÉO-QUÉBEC, 2016, p. 107126). More than forty sites in the immediate region have been prepared for presentation to the public in one manner or another, ranging from the major sites just described, to the presentation of archaeological features, street markings, or interpretive panels (MOSS, 2015). When one considers the quantity and quality of sites open to the public, it is easy to imagine the significant contribution of archaeological heritage to the regional economy.

There have also been associated advantages for the city's collaborators. One project in particular, the Auberge Saint-Antoine hotel complex, which was developed by a private owner in the heart of The Historic District of Old Québec, is worthy of mention (Figure 3). Although this was a private-sector initiative, both the City of Québec and the province worked closely with the developer to ensure the fluid integration of the newly restored - and at times reimagined buildings' construction into the historic fabric of the Historic District. The rich archaeological heritage of the site is fully integrated into the design concept of the complex, which is considered an archaeological hotel. ${ }^{5}$ Features and interpretive displays are open to the general public in several areas of the hotel, such as the lobby, the conference zone, the hotel's Café-Bar Artéfact, and the hallways. Each of the six floors is associated with a different time period and a different historical figure from the site. Artefact displays are placed in controlled-access portions of the hotel, such as elevators and corridors, while custom-designed furniture displays artefacts from the

5 The hotel's web page provides ample examples of this: www.saintantoine.com/en/hotel. 
corresponding period in each room. A publication for the general public that was prepared on the project (LAPOINTE, 2007) complements several scientific publications (CLOUTIER, 2006; ROULEAU et al., 1998b; SIMONEAU, 2008). The City has further contributed to this project by marking three former limits of the St. Lawrence River shoreline in the pavement just beside the hotel, next to the restored $18^{\text {th }}$ century stone wharves. The Auberge SaintAntoine is routinely cited as an example of private-public collaboration for the promotion of archaeological heritage, and it can be seen as an innovative fusion of place making and commercial development. In addition to receiving a long series of awards from the hotel industry (AUBERGE SAINT-ANTOINE, 2015), the hotel won the prestigious Heritage Canada National Trust for Canada National Achievement Award in 2008, notably "...for the restoration of its hotel and museum, and its commitment to heritage conservation [...] to incorporate and display the artefacts found on the site during the eight-year archeological dig. Used as a cannon battery in wartime and a centre of merchant trade in peace time, the site, known as Îlot Hunt, produced an array of artefacts that can now be seen in the Auberge's museum" (HERITAGE CANADA NATIONAL TRUST FOR CANADA, 2008).

Figure 3

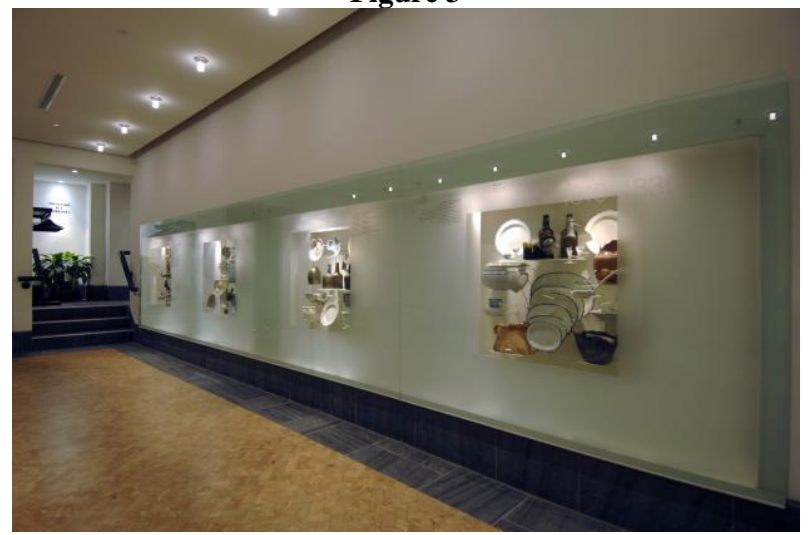

The Auberge Saint-Antoine has archaeological interpretive modules throughout the public and private parts of the hotel complex. (Photo by Victor Diaz Lamich; courtesy of Auberge Saint-Antoine.) 
At another site, in the Lower Town, display modules interpret the results of excavations on the site of the royal shipyards and the $19^{\text {th }}$ century markets at the entrance of the Gare du Palais train station, one of the principal points of entry for tourists. The station is a stone's throw from the Îlot des Palais archaeological site, Université Laval's field school. An archaeological interpretation centre was opened in 2014 on this municipal property by a heritage association affiliated with the City. Interpretive panels and modules have also been installed in Place d'Youville, a public square situated at another entrance to the walled Historic District of Old Québec, in front of the $18^{\text {th }}$ century ramparts that are so characteristic of the fortified city (Figure 4). Field projects are also interpreted for the general public when and where possible. Recent excavations at City Hall, within the Collège des Jésuites complex, an $18^{\text {th }}$ century college that also served as army barracks during the $19^{\text {th }}$ century, were accompanied by onsite guides.

Figure 4

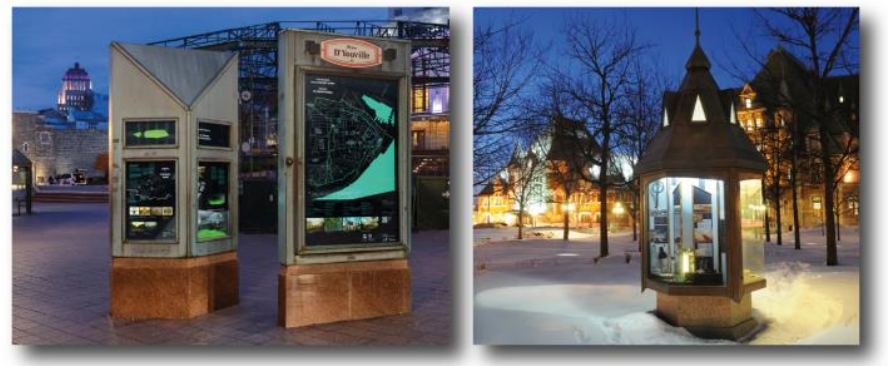

Archaeological interpretive modules have been placed in two public squares at important entry points to The Historic District of Old Québec, namely, in Place d'Youville, in front of the ramparts, and in Place de la Gare, in front of the intermodal train station. (Photos by Chantal Gagnon and Robert Greffard; courtesy of Ville de Québec.)

Interest in archaeological heritage extends beyond the Historic District; indeed, several other sites have been developed and interpreted for the public. These projects are based on intensive research and are developed as a part of a movement of place making and, more generally, public education. The massive ruins of the church of Notre-Dame-de- Foy, in Sainte-Foy, now called the Parc de 
la Visitation Historical Site, have been stabilized and are used for open-air concerts. Another park, the Parc du Vieux-Passage, in the Limoilou district, contains a scaled-down reconstruction of a temporary fortification, a bridgehead hastily constructed in 1759 to prevent the invading British from crossing the St. Charles River and reaching the fortified Upper Town. Another module, completed in 2014 in the Charlesbourg Historic District's Parc du Sacré-Coeur, was constructed at the request of the parish's heritage committee and the borough council to commemorate the town's first church (Figure $5)$.

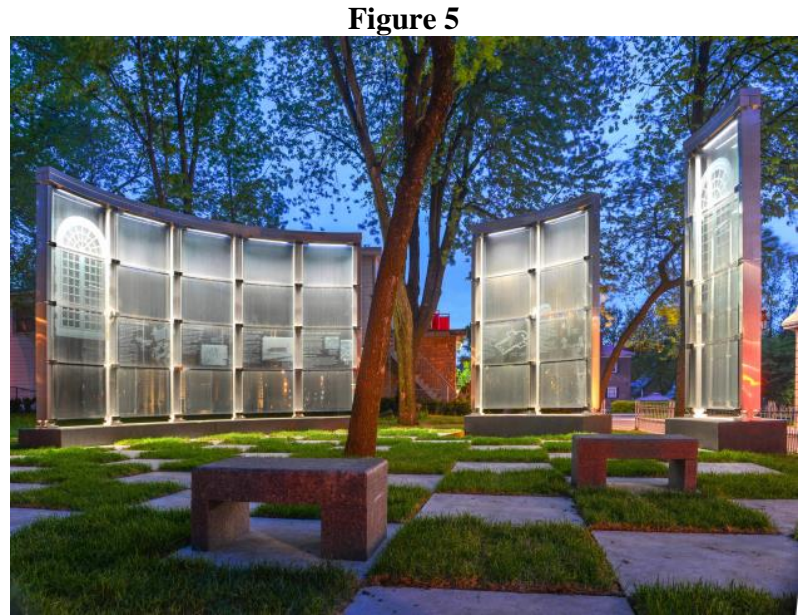

The City installed a full-scale module over the remains of a former village's first church, in Parc du Sacré-Cœur, in the heart of the Charlesbourg Historic District. (Photo by Robert Greffard; courtesy of Ville de Québec.)

Another example of the City's close partnership with local organizations can be found at the Nativité de Notre-Dame de Beauport church, in the heart of the Beauport Historic District. While improving public space surrounding the church, the City worked with the parish council and the local historical society, the Société d'art et d'histoire de Beauport, to design a new public space and a monument erected in honour of the founding families of one of New France's first communities. The Société d'art et d'histoire de Beauport 
assumed the role of developer for the archaeological research project, hiring archaeologists and crews over three years of excavations and monitoring. A synthesis of the three-year project was produced by the Société in 2014 (ROY, 2014).

In Cap Rouge, the development of management tools for important archaeological resources for this former $19^{\text {th }}$ century village were created in a collaboration with the City and the Société historique du Cap-Rouge. This contributed to local pride. Another collaboration, with the Association pour la protection de l'environnement du lac Saint-Charles et des Marais du Nord, focussed on the presence of First Nations in the environment around what is now the city's drinking-water reservoir (MOSS, 2011; PLOURDE \& BAIN, 2009).

These projects are accessible to the local community as well as to tourists, and efforts are made to keep citizens informed. For residents, the results of twenty-five years of research on more than forty sites have been summarized on a series of web pages dedicated specifically to archaeology ${ }^{6}$ (VILLE DE QUÉBEC, 2014), and in 2010 and 2011, four-panel foldouts were inserted into the City's quarterly newspaper, which was distributed to each of the City's 200,000 households (VILLE DE QUÉBEC, 2010, 2011).

\section{Heritage legislation and approaches to archaeology in the province of Québec}

In Canada, there is no overarching federal heritage legislation for archaeology because heritage issues fall under provincial jurisdiction (POKYTYLO \& MASON, 2010). Each province defines its own approach to heritage matters, and political objectives and programmes vary from province to province. 
In the province of Québec, renewed heritage legislation came into effect in 2012. The new Cultural Heritage Act (NATIONAL ASSEMBLY, 2011) replaced the 1972 Cultural Property Act (see MCC, 2012, for a brief history of heritage legislation in the province of Québec). It imposes legal constraints on the practice of archaeology - compulsory permits for archaeologists, the obligation to declare all discoveries, the possibility of halting work on construction projects to protect archaeological sites and remains - and offers municipalities additional powers for the protection and enhancement of cultural resources. It is interesting to note that certain provisions of this legislation are renewed directives of the preceding Cultural Property Act of 1972, notably the provisions concerning permitting. They are based on legislation enacted by France's Vichy government in 1941, known as "la loi Carcopino" after the minister who had it drafted with the intent of protecting archaeological heritage from the Nazi occupiers (RÉPUBLIQUE FRANÇAISE, 1941; KARLSGODT, 2011, p. 296). In France, the 1941 legislation was replaced by the Code du patrimoine, in 2001. In contrast, in Québec, the 1941 legislative framework was maintained in Quebec's 2012 Cultural Heritage Act.

No provisions were introduced in the 2012 Act to define developers' financial or procedural responsibilities. By not replacing the 1941 framework, Québec reinforced the ambiguous position of archaeological practice, on a continuum from government-controlled to development-led. For example, it did not adopt the modifications to the French model to implement the Valletta Treaty, as defined by the European Convention on the Protection of the Archaeological Heritage (COUNCIL OF EUROPE, 1992, DEMOULE, 2007, 2010). In the UK, where archaeology is also covered by the Valetta Treaty, planning-led archaeology is the major source of archaeological activity and is enthusiastically lauded as such (HISTORIC ENGLAND, 2015), although it has recently come under considerable pressure (SOUTHPORT GROUP, 2011).

Nor did Quebec adopt a compliance-driven approach, as is now generally practiced in North America where developers assume the full cost of archaeology associated with their projects. As such, Québec's cultural heritage legislation is notably different from that of its Canadian neighbours, such as the province of Ontario (see 
WILLIAMSON et al., 2017), and its American neighbours, who, at the national level, rely almost entirely on private consulting firms to respond to the requirement of section 106 of the Historic Preservation Act (APPLER, 2017, p. 183-185; PEACOCK \& RAFFERTY, 2007).

Yet despite the absence of explicit legislation requiring preventive or development-led archaeology, there is an expectation on the part of the provincial government that municipalities adopt a compliance-driven approach. Archéo-Québec (2012), a non-profit heritage association, produced an introduction to preventive archaeology with funding and guidance from the MCC. This guide, Archéologie préventive : Guide pratique à l'intention des municipalités du Québec, explicitly defines an approach similar to that developed by France's Institut national de recherches archéologiques préventives ( $t r$. national institute for preventive archaeological research), usually referred to by its acronym, INRAP, with the stated intention of counselling municipalities that have no inhouse expertise in archaeology. Although it is an articulate expression of the MCC's new expectations, it contains no specifications concerning financial responsibilities.

The new Cultural Heritage Act is changing the nature of archaeological practice, and future iterations of the Entente sur le développement culturel will be modified in the context of the new Act. The City of Québec has adopted a proactive position in order to ensure continuity with past successes and newly created traditions of working with residents and promoters.

The City is preparing a bylaw congruent with the new Act. It is hoped that funds traditionally available in the memoranda of agreement with the provincial government can be used to support projects carried out by private citizens or small-scale developers under the new programmes. Although the City is not required to do so by law, the City has directed its archaeological team to prepare an archaeological master plan to underpin the proposed bylaw. This plan will be integrated into the municipal GIS-based management system.

The master plan is based on a database of more than 900 known sites in Québec City identified in the province's Inventaire des sites archéologiques du Québec (MCC, 2014) and on a series of potential locations for archaeological sites identified through 
predictive modelling. The identification of potential pre-contact First Nations occupations is based on environmental data, including distance from water sources, slope (less than 10\%), soil drainage, and historic-era land-disturbance activities. More than 1,000 potential areas have been selected for future examination (PLOURDE, 2013). Historic-period sites are identified using written sources, such as maps and reports about the history of the city. The master plan, named Système intégré de gestion en matière d'archéologie (SIGMA), is an open system; new data can be added, and existing data can be corrected at any time (SIMONEAU, 2011, 2014).

The efficacious application of an archaeological bylaw and the full use of the archaeological master plan will require policies and programmes that foster public interest and promote public participation. Because the Act does not attribute financial responsibility to any particular actor in this context, the City has deemed it important to respect the financial capacity of property owners. The City Archaeologist is thus drafting a programme that offers financial support for small-scale property owners or developers. Without such a programme, it will be the responsibility of developers to assume all associated costs, which would in all likelihood impose a barrier to the implementation of this approach.

\section{A Critical Regard}

Drawing on Dawdy's "cranky challenge," as she so cogently puts it (2009a, p. 139), certain caveats are necessary to put this positivist portrait into a wider perspective and to fully reply to the questions "Is archaeology useful?" "Should archaeology be useful?" and "Can archaeology save the world?" In short, what has been useful in Québec City, and what world has been saved?

The projects carried out by the municipality, indeed, most of the projects within the city limits, fall within the general definition of public archaeology: site development and interpretation, the process of "place making," and the consolidation of cultural identity (MOSS, 
2011). The latter may in part be a spinoff of the Historic District's World Heritage status, but the nature of the projects suggests, rather, that it represents a genuine and deep-seated interest in local heritage. There are very few instances of the instrumental use of archaeology to oppose urban development projects; this is likely another indication of the genuine nature of interest in archaeological heritage, because it is appreciated for its intrinsic value rather than for its usefulness to achieve other ends.

The unequivocal contribution of archaeological heritage projects to the socioeconomic fabric of the City may also be due to the specificities of Québec society, particularly its tendency to strongly value the province's cultural identity. As noted by Christina Cameron, the Université de Montréal's Canada Research Chair on Built Heritage, when speaking on heritage management: "When compared to the rest of Canada, Quebec is more advanced in its reflections, is more interested and involved. [...] this is because of the relationship between culture-language-identity-heritage ..." (LALONDE, 2010, author's translation). Québec very clearly has a distinctive culture in North America: the province's well-known independence movement is a concrete political expression of this cultural reality. Nationally, Parliament has recognized that the Québécois form a nation within a united Canada in a resolution adopted in the House of Commons on November 27, 2006 (HOUSE OF COMMONS, 2006).

In Québec City, archaeology is closely linked to the heritage community. Therefore projects clearly fit into the mold of "government archaeology" as defined by Dawdy (2009b, p. 190). As such, these projects should be exempt from the kinds of financial and "existential" insecurities that may await millennial archaeology. And they would be exempt, were it not for the unfortunate co-occurrence of, on the one hand, a blind spot in the archaeological community's perception of its own praxis and, on the other, shortcomings in the 2012 heritage legislation.

With the notable exception of research programmes developed by Universite Laval in collaboration with the City that foster an ecosystemic and environmental approach, projects rarely venture far from the theme of the colonial past. In general, there is a pervasive discourse on empire, particularly of that of the French 
regime (1608-1763), typified by Place-Royale, but also of the English regime (1763-1867), as seen through the fortifications and administrative complexes, such as the Saint-Louis Forts and Châteaux National Historic Site. A recent project at the 1541-1543 site of the attempt to establish the first French colony in the Americas (by Jacques Cartier and the Sieur de Roberval) is representative of this trend (SAMSON \& FISET, 2013). Analysis concentrated on such aspects of the site as the presence of nobility, which reinforced the "imperial" importance of the finds to the detriment of new lines of inquiry. One such line suggests itself: Could the site indicate emerging models of European relations with indigenous nations in a rapidly expanding world, similar to those studied in South America or on the African sub-continent? Perhaps it could, but interpretation of the site has been confined to illustrating the political relations prevailing amongst European nations in the late-medieval world.

The heritage community in Québec City can be critical of itself. It has engaged in in-depth analysis of the Place-Royale project (FAURE, 1992) or, more recently, of the consequences of World Heritage status itself (MORISSET, 2016). However, archaeologists have only rarely engaged in objective analysis of their own output. One exception is the evaluation of the research programme on PlaceRoyale, in which Auger and Moss (2001, p. 141) note the manner in which nationalist ideologies precluded consideration of the "messy" period of the "slumification" of the seat of French civilization in North America from 1860 to 1960 :

It is possible to see the effect of ideologies behind the project for the urban renewal of Place-Royale, particularly when it comes to archaeological research in Quebec City. By focusing on a presumed golden age the French Regime - a crucial period in the evolution of the city, that of a certain decline from 1860 to 1960, was completely pushed aside. This has obscured any objective reference to the process of "slumification". The City and its partners have indeed made important efforts to prevent Old Town from turning into a museum by systematically maintaining a resident local population. There is a strong desire to avoid one of the major pitfalls 
of heritage conservation, that is, allowing the city to become a parody of itself, as has occasionally occurred elsewhere and as some have said has happened with Place-Royale. But the abatement of this process will only succeed if based on accurate and objective knowledge of the city itself.

In short, archaeology in Québec City is increasingly projecting a stereotyped image of the discipline and of the past it seeks to understand. The heritage industry is a predominant and admittedly successful paradigm for action, but without further discussion of the knowledge we hope to acquire, archaeologists will not be able to elucidate the fundamental values guiding our work.

Dawdy (2009a, p. 140) had words for this too: "I am suggesting that it may be more ethical and more useful to set archaeology free from history and heritage - in other words, that we reorient archaeology away from reconstructions of the past towards problems of the present." Commenting on this, Holtorf (2009, p. 185) wonders "to what extent cultural resource management, commercial archaeology and public outreach projects themselves 'apply' archaeology or make it useful for solving problems of the present." In other words, archaeology may be avoiding problems rather than working on resolving them.

Has the attribution of World Heritage status to the Historic District contributed to this process? Possibly, but the tendency was in place years before the UNESCO World Heritage listing. Also, the positive contribution of archaeology to the region's socioeconomic fabric has spread well beyond the limits of the Historic District and beyond the limits of the three other historic districts within the city. However, having missed the opportunity to objectively evaluate the discipline in the recent process of renewing heritage legislation, we are still not in a position to adjust current practice to the kinds of contemporary problems that have found solutions in other jurisdictions. Moreover, without an objective appreciation of the plentiful and technically exemplary work done in Québec City over the past half-century, and the necessary repositioning of the intellectual trajectory of a dynamic and proficient professional 
community, archaeology will simply return to the values underlying the "loi Carcopino" and the nationalistic preoccupations it addressed in 1941. To paraphrase Dawdy (2009b, p. 189), what will be missing is not the past - it's all around - but an imagined and shared future. ${ }^{7}$

\section{Bibliography}

APPLER, D. Toward a Theory of Municipal Archaeology: Why Local Government Should Become Public Archaeology's New Best Friend. In S. Baugher, D. Appler \& W. Moss (eds), Urban Archaeology, Municipal Government and Local Planning Preserving Heritage within the Commonwealth of Nations and the United States, New York: Springer, 2017, p. 183-201.

ARCHÉO-QUÉBEC. Archéologie préventive. Guide pratique à l'intention des municipalités du Québec. [Electronic document]. www.archeoquebec.com/sites/default/files/archeologie_preventive_gu ide_pratique.pdf, 2012.

ARCHÉO-QUÉBEC. D'escales en découvertes, l'archéologie raconte le Québec. Un guide proposé par le réseau Archéo-Québec. [Electronic document]. http://www.archeoquebec.com/sites/default/files/guide decouvertes 09-14_150ppi optimise.pdf. 2016.

AUBERGE SAINT-ANTOINE. Distinctions and Awards [Electronic document]. http://www.saint-antoine.com/en/hotel/awards. 2015.

AUGER, R., \& MOSS W. An Archaeology of Physical and Social Transformation: High Times, Low Tides and Tourist Floods on

7 It is noteworthy that a conference on the theme "Archaeology and Futurity" was held in April 2016 at Brown University's Joukowsky Institute for Archaeology and the Ancient World. Our imagined future obviously continues to preoccupy us! See: https://blogs.brown.edu/archaeology/workshops/archaeology-and-futurity/. 
Quebec City's Waterfront. In: A. MAYNE \& T. MURRAY (eds.), The Archaeology of Urban Landscapes: Explorations in Slumland. Cambridge, UK: Cambridge University Press, 2001, p. 132-144.

BAUGHER, S., APPLER D. \& MOSS W. Introduction. Thinking Globally and Acting Locally: Exploring the Relationships Between Community, Archaeological Heritage, and Local Government. In S. Baugher, D. Appler \& W. Moss (eds), Urban Archaeology, Municipal Government and Local Planning - Preserving Heritage within the Commonwealth of Nations and the United States, New York: Springer, 2017, p. 1-16.

CLOUTIER, C. (MOSS W., Dir.). Les battures du Saint-Laurent aux XVIIe et XVIIIe siècles : un dépotoir à ciel ouvert? Le cas du site archéologique de l'îlot Hunt. Cahiers d'archéologie du CELAT $n^{\circ} 19$. Québec, QC: CELAT, Ville de Québec and Ministère de la Culture et des Communications, 2006.

COMMUNAUTÉ MÉTROPOLITAINE DE QUÉBEC (CMQ). Cartes et statistiques [Electronic document]. http://www.cmquebec.qc.ca/cartes-statistiques, 2015.

COUNCIL OF EUROPE. European Convention on the Protection of the Archaeological Heritage (Revised) and Explanatory Report. European Treaty Series (143). Strasbourg, FR: Council of Europe, 1992.

DAWDY, S. L. Millenial archaeology. Locating the discipline in the age of insecurity, Archaeological Dialogues, N. 16, n 2, p. 131-142, 2009a.

DAWDY, S. L. Doomsday confessions, Archaeological Dialogues, N. 16, n 2, p. 186-193, 2009b.

DEMOULE, J.-P. Scientific quality control and the general organisation of French archaeology. In W. J.H. Willems \& M. van den Dries (eds.), Quality Management in Archaeology. Oxford: Oxbow Books, 2007, p. 135-147.

DEMOULE, J.-P. The crisis - economic, ideological and archaeological. In N. Schlanger \& K. Aitchison (eds.). Archaeology 
and the Global Economic Crisis. Multiple Impacts, Possible Solutions (p. 13-17). Tervuren, BE: Culture Lab Éditions, 2010, p. 13-17.

DUFAY, B., HINCKER V. \& VIAND A. Les archéologues et la lampe d'Aladin. L'archéologie "pour" la ville. In: B. Dufay, V. Hincker \& A. Viand (eds.) Les Nouvelles de l'archéologie, n. 136, p. 3-5, 2014.

ÉDITEUR OFFICIEL DU QUÉBEC. Cultural Heritage Act, chapter P-9.002, 2017.

FAURE, I. La reconstruction de Place-Royale à Québec, Cahiers de géographie du Québec, N. 36, n. 98, p. 321-336, 1992.

GENOIS LEDUC, J.-M. \& LEDUC G. La découverte, Le Soleil, Québec, N. 120, n. 6, p. 40, November 5, 2016.

HERITAGE CANADA THE NATIONAL TRUST. National Achievement Award. [Electronic document]. https://www.heritagecanada.org/en/get-involved/awards/formernational-trust-awards/national-achievement-award, 2008.

HISTORIC ENGLAND. Building the Future, Transforming our Past. Celebrating development-led archaeology in England, 1991-2015. [Electronic document]. https://content.historicengland.org.uk/imagesbooks/publications/building-the-future-transforming-ourpast/building-future-transforming-past.pdf/, 2015.

HOLTORF, C. Archaeology. From usefulness to value, Archaeological Dialogues, n. 16(2), p. 182-186, 2009.

HOUSE OF COMMONS. $39^{\text {th }}$ Parliament, $1^{\text {st }}$ Session, Edited Hansard, Number 087, Monday, November 27, 2006. [Electronic document]. http://www.ourcommons.ca/DocumentViewer/en/391/house/sitting-87/hansard, 2006.

KARLSGODT, E. C. Defending National Treasures: French Art and Heritage Under Vichy. New York, NY: Stanford University Press, 2011.

LALONDE, C. Université de Montréal - Le patrimoine bâti a trouvé sa voie. L'architecture certes, mais aussi le paysage et l'urbanisme, Le 
Devoir, 23 October 2010 [Electronic document]. http://www.ledevoir.com/societe/actualites-ensociete/298561/universite-de-montreal-le-patrimoine-bati-a-trouvesa-voie. 2010.

L'ANGLAIS, P.-G. (MOUSSETTE, M. Dir.). La recherche archéologique en milieu urbain: d'une archéologie dans la ville vers une archéologie de la ville. Les Cahiers du CÉLAT, hors série $n .6$. Quebec: CÉLAT, Université Laval, 1994.

LAPOINTE, C. Past Perfect. Quebec: Éditions Sylvain Harvey, 2007. MINISTÈRE DE LA CULTURE ET DES COMMUNICATIONS (MCC). Histoire de la protection du patrimoine au Québec. [Electronic document]. www.mcc.gouv.qc.ca/index.php?id=5122, 2012b.

MINISTÈRE DE LA CULTURE ET DES COMMUNICATIONS (MCC). Bibliographie de l'Inventaire des sites archéologiques du Québec (ISAQ). [Electronic document]. www.mcc.gouv.qc.ca/index.php?id=3355\&tx_lesecrits_pi1\%5Becrit \%5D=683\&cHash=402531f81acda53805fb58ab08991b23, 2014.

MORISSET, L. K. Québec ou le patrimoine augmenté, Continuité, n. 148, p. 30-34, 2016.

MOSS, W. Cent vint-cinq ans de découvertes. Une bibliographie sur l'archéologie de la ville de Québec. Mémoires vives, n. 5, p. 14-24, 1993.

. Quebec City, Canada. In L. A. Decunzo \& J. H. Jameson Jr. (eds.). Unlocking the Past. Celebrating Historical Archaeology in North America. Gainesville, FL: Society for Historical Archæology and University Press of Florida, 2005, p. 82-88.

. The recent archaeology of the early modern period in Québec City. Post-Medieval Archooology, n. 43(1), 2009a.

. Introduction: the archaeology of a North American city and the early modern period in Québec. In MOSS, W. 2009a, The recent archaeology of the early modern period in Québec City. PostMedieval Archaeology, n. 43(1), p. 1-12, 2009b. 
- Choosing Archaeology in Quebec City, Toward an archaeological agora: the public as participants and creators of archaeological knowledge and understanding, Society for Historical Archaeology, Austin, Texas, 2011.

. L'archéologie urbaine à Québec : un passé qui a de l'avenir, Chaire pour le développement de la recherche sur la culture d'expression française en Amérique du Nord (CEFAN), Université Laval. Québec, QC, October 8, 2015.

MOUSSETTE, M. \& MOSS W. Quebec, New World City and Colonial Atlantic Port: An Archaeological Perspective. In William: W. KELSO (ed.). Archaeology of Early European Colonial Settlement in the Emerging Atlantic World. Society for Historical Archaeology, Special Publication Series n. 8, 2010, p. 51-72.

MOUSSETTE, M. and WASELKOV G. Archéologie de l'Amérique coloniale française. Montréal, QC: Lévesque éditeur, 2013.

NATIONAL ASSEMBLY. Cultural Heritage Act. Quebec Official Publisher, Quebec, QC. [Electronic document]. www2.publicationsduquebec.gouv.qc.ca/dynamicSearch/telecharge.p hp?type $=5 \&$ file $=2011 \mathrm{C} 21 \mathrm{~A} . \mathrm{PDF}, 2011$.

PEACOCK, E. \& RAFFERTY J. Cultural resource management guidelines and practice in the United States. In W. J.H. Willems \& M. van den Dries (eds). Quality Management in Archaeology. Oxford, UK: Oxbow Books, 2007, p. 113-134.

PLOURDE, M. Étude du potentiel archéologique de l'occupation amérindienne du territoire de la ville de Québec. Quebec, QC: Ville de Québec (Service de l'aménagement du territoire) \& Ministère de la Culture et des Communications, 2013.

PLOURDE, M. \& BAIN A. Fouilles archéologiques, Marais du Nord, lac Saint-Charles : Chantier-école en préhistoire de l'Université Laval, saison 2009 et synthèse des travaux archéologiques (20012009). Cahiers d'archéologie du CELAT 30, 92 pages. CELAT, Université Laval, 2009. 
POKYTYLO, D. \& MASON A. R. Archaeological Heritage Resource Protection in Canada. The Legislative Basis. In: P. Mauch Messenger \& G. S. Smith (eds.). Cultural Heritage Management, A Global Perspective. Gainesville, FL: University Press of Florida, 2010, p. 48-69.

RÉPUBLIQUE FRANÇAISE. Loi du 27 septembre 1941 portant réglementation des fouilles archéologiques. Journal officiel de la République française. [Electronic document]. www.archeodroit.net/Textes/Terrain/loi1941.html, 1941.

ROULEAU, S. Charles Aubert and Quebec City's Ports in the 17th Century. In C. Dagneau \& K. Gauvin (eds). ACUA Underwater Archaeology Proceedings 2014 (p. 13-19). Advisory Council on Underwater Archaeology, 2014, p. 13-19.

ROULEAU, S., LALANDE D., FORTIN C. \& L'OSTÉOTHÈQUE DE MONTRÉAL INC., W. MOSS (Dir.). L'archéologie du monastère des Récollets à Québec (CeEt-563). Les Cahiers d'archéologie du CELAT $n^{\circ}$ 4. Québec, QC: CELAT, Ville de Québec and Ministère de la Culture et des Communications, 1998a.

ROULEAU, S., CLOUTIER C., FORTIN C. \& L'OSTÉOTHÈQUE DE MONTRÉAL INC., W. MOSS (Dir.). L'archéologie de la maison Aubert-de-la-Chesnaye à Québec (CeEt-46). Les Cahiers d'archéologie du CELAT $n^{\circ}$ 3. Québec, QC: CELAT, Ville de Québec and Ministère de la Culture et des Communications, 1998b.

ROY, C. (W. MOSS, Dir.). Scènes de la vie paroissiale. L'archéologie de la place de l'église de La Nativité de Notre-Dame à Beauport. Les Cahiers d'archéologie du CELAT $n^{\circ}$ 39. Québec, QC: CELAT, Ville de Québec, Ministère de la Culture et des Communications and Société d'art et d'histoire de Beauport, 2014.

ROY, O. Trente ans de chantiers-écoles en archéologie. Au fil des événements, N. 48, n 3. [Electronic document]. www.lefil.ulaval.ca/articles/trente-ans-chantiers-ecoles-archeologie34004.html, 2012.

SAMSON, G, \& R. FISET. Chantier archéologique CartierRoberval. Promontoire du cap Rouge (CeEu-4), Québec, Canada. 
Rapport synthèse des fouilles 2007-2008. Québec, QC: Commission de la Capitale-Nationale du Québec. [Electronic document]. http://www.capitale.gouv.qc.ca/system/documents/media/000/000/13 0/original/6_177_Rapport.Cartier-Roberval-BQ_br.pdf?1442924719, 2013.

SIMONEAU, D. (W. MOSS, Dir.). Le Séminaire de Québec: 140 ans de recherches archéologiques. Les Cahiers d'archéologie du CELAT $n^{\circ}$ 22. Québec, QC: CELAT, Ville de Québec and Ministère de la Culture, des Communications et de la Condition féminine, 2008a.

SIMONEAU, D. (W. MOSS, Dir.). L'îlot Hunt: dix ans de recherches archéologiques. Les Cahiers d'archéologie du CELAT $n^{\circ} 23$. Québec, QC: CELAT, Ville de Québec and Ministère de la Culture, des Communications et de la Condition féminine, 2008b.

SIMONEAU, D. SIGMA II, présentation des principes de sa mise en place. Québec, QC: Ville de Québec, Service de l'aménagement du territoire, 2011.

SIMONEAU, D., with W. MOSS. SIGMA II. Élaboration des critères de qualification: document de présentation et de réflexion. Québec, QC: Ville de Québec, Service de l'aménagement du territoire, 2014.

SOUTHPORT GROUP. Realising the Benefits of Planning-Led Investigation in the Historic Environment: A Framework for Delivery. Chartered Institute for Archaeologists, London, England. [Electronic Document]. $\quad$ www.archaeologists.net/sites/default/files/nodefiles/SouthportreportA4.pdf, 2011.

STATISTICS CANADA. 2012 International Travel Survey Microdata (66C001) and/or 2012 Travel Survey of Residents of Canada Microdata (87M006XDB96000), Le tourisme dans les villes canadiennes (projet CITIES), 2016.

VILLE DE QUÉBEC. L'avenir maintenant. Plan directeur d'aménagement et de développement. [Electronic document]. http://www.ville.quebec.qc.ca/apropos/vie_democratique/administrati on/planification/pdad/, 2005. 
_. Politique du patrimoine. [Electronic document]. http://www.ville.quebec.qc.ca/publications/docs_ville/politique_patri moine.pdf, 2007.

document].

. L'archéologie par les sites et les siècles. [Electronic http://www.ville.quebec.qc.ca/culture_patrimoine/docs/archeologie/V Q CahierArcheologie Lres.pdf, 2010.

document].

. L'archéologie par les places et par les parcs. [Electronic http://www.ville.quebec.qc.ca/culture patrimoine/docs/archeologie/V Q_CahierArcheologie2011.pdf, 2011.

L'archéologie à Québec.
http://archeologie.ville.quebec.qc.cal, 2014.

[Electronic document].

hill/archeologie.ville.quebec.qc.cal, 2014.

$\begin{array}{lrr}\text { Vision patrimoine 2017-2027. } & \text { Préserver-Enrichir- } \\ \text { Transmettre. } & \text { [Electronic }\end{array}$ http://www.ville.quebec.qc.ca/culture patrimoine/patrimoine/vision patrimoine/, 2016.

WILLIAMSON, R. F., D. A. ROBERTSON \& S. HUGHES. Archaeological Resource Management in Toronto: Planning, Preservation and Interpretation, In S. Baugher, D. Appler and W. Moss (Eds.), Urban Archaeology, Municipal Government and Local Planning - Preserving Heritage within the Commonwealth of Nations and the United States. New York, NY: Springer, 2017, p. 69-89.

RECEBIDO EM: 01/10/2017 APROVADO EM: 10/12/2017 